sis and production of the antibiotics are examined and questions of gene organization and gene expression are explored in light of recent advances in genetic engineering and manipulation. In brief, the first three chapters deal with the genetics of the most important microbial antibiotic producers and detail the range of metabolic controls that affect antibiotic production. The remainder of the book is devoted to the biosynthesis of commercially important groups of antibiotics and relates genetic and metabolic control systems in the producing organism to antibiotic production.

The value of this book to those involved in the pharmaceutical industry is that all of the new, useful information on microbial production of antibiotics is very well organized, all in one place, and could be helpful to those involved with the description of applications of genetic engineering to antibiotic production. (Circle No. 203 on Reader Service Card.)

In addition to the various books, journals, serials, and newsletters on biotechnology, an encyclopedia-like comprehensive treatise on biotechnology has just been released. Published by Verlag Chemie International, a well-respected publisher of technical material for scientific research, and entitled Biotechnology, H.-J. Rehm and G. Reed, Eds., this eight-volume series should be a welcome addition to the field's sources of information. (See BIO/TECHNOLOGY, 1:1 p. 79) It is aimed particularly at those in volved in industrial microbiology and development and expansion of microbial processes. Volume 1, Microbial Fundamentals, and volume 3, Biomass, Microorganisms for Special Applications, Microbial Products I, Energy from Renewable Resources, are now available. Forthcoming volumes cover topics ranging from biochemical engineering to food and feed production with microorganisms. (Circle No. 204 on Reader Service Card.)

\section{BIOTECH '83}

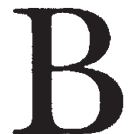

iotech '83, the first world conference and exhibition on the commercial applications and implications of biotechnology is taking place this month in London. Accompanying the conference will be the first international biotechnology exhibition. Displays from many of the world's leading biotech companies are on hand, along with a variety of products and services. Everything from process plant equipment and fermenters to instrumentation, reagents, and chemicals are represented.
Amicon Ltd shows a new series of electrically powered modular systems for the processing of interferon, virus preparations, enzymes, hormones, plasma and serum fractions, and fermentation broths. This system should be interesting to those involved in industrial applications, for the system can handle batches that range in size from 10 to several thousand liters or continuous runs of larger volumes.

Pharmacia Chemicals, well known to all involved in separation technology, shows its complete line of production equipment in addition to its laboratory chromatography and electrophoresis supplies.

New Brunswick Scientific shows its newly developed pilot plant industrial fermenter. This will be available in sizes from 10 to 500 liters. The company also offers its Biosearch DNA synthesizer, called the Synthesis Automation Machine (SAM), which automates synthesis of polypeptides and oligonucleotide fragments.

LKB Instruments, familiar to those in the field for its line of reliable laboratory equipment, exhibits its Macrodrive DNA/RNA sequencing system and its BioActivity Monitor for microbial growth studies. Gelman Science highlights its Acroflux filtration unit, a filtration unit for concentrating and harvesting bacteria which allows direct scale-up to production size amounts of the same culture.

Cambridge Biotechnology Laboratories displays its quality line of products, including restriction enzymes, DNA transillumination equipment, and Gel electrophoresis apparatus. Other new fermenters are being shown by Roth Scientific, Rintekno, LH Fermentation, and Electrolux.

Bio-Rad Laboratories features its popular Model 600 Protean Electrophoresis Cell along with a variety of new power supplies. Whatman Ltd. displays its new Prep-25 column for pilot plant protein separations.

Lab $\mathbf{M}$ offers custom formulations which can be blended and quality controlled like its standard products. There is a potential for this product to be a real time-saver. Pall Process Filtration shows its special membrane for RNA and DNA transfer techniques. Called Biodyne $A$, this membrane returns a 500 -fold increase in efficiency in RNA retention over nitrocellulose, and for southern transfers provides excellent reproducibility and high strength. (Circle No. 205 on Reader Service Card for above Biotech '83 participants.)

David L. Marcus, Ph.D., is the Product Review editor of BIO/TECH. NOLOGY. All product information for this section should be addressed to Dr. Marcus at the editorial offices of BIO/TECHNOLOGY.

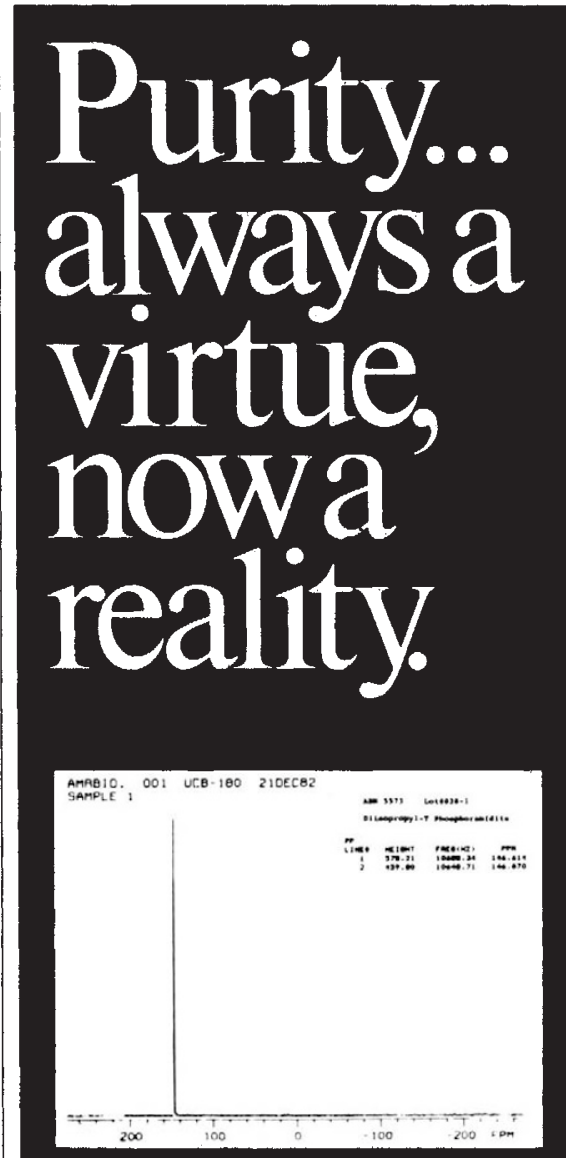

When you need purity and product integrity, you need American BioNuclear.

We synthesize each Nucleoside, Reagent and Phosphoramidite under the strictest production protocols. Then we test and retest with the finest state-of-the-art techniques and analytical instruments to insure the purest compounds possible.

At American BioNuclear

we are more than a laboratory. we are manufacturing chemists who take raw materials and transform them into fine organic and biochemical compounds.

American BioNuclear. .

precision organic and biochemical materials for DNA synthesis.

\section{American BioNuclear}

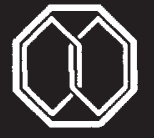

4.5611 Horton Street

Emeriville. (A 140018

$415 / 0.52-4406$

Circle No. 96 on Reader Service Card 